\title{
Risk of HIV-associated Hodgkin lymphoma during the first months after initiation of combination antiretroviral therapy
}

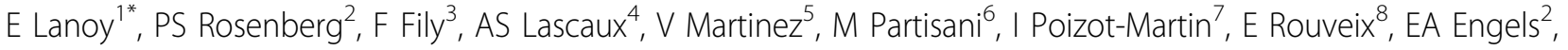 \\ D Costagliola1, ${ }^{1,9}$, J Goedert ${ }^{2}$
}

From $12^{\text {th }}$ International Conference on Malignancies in AIDS and Other Acquired Immunodeficiencies (ICMAOI)

Bethesda, MD, USA. 26-27 April, 2010

\section{Background}

Since the advent of combination antiretroviral therapy (cART), several studies have described an increase in the incidence of Hodgkin lymphoma (HL). This increase has been postulated to be linked with immunologic mechanisms occurring at cART initiation. Relationships between the CD4 cell count and the risk of HL have also been investigated. Our study aimed to evaluate the risk of HL by use of cART and its duration.

\section{Materials and methods}

From the French Hospital Database on HIV (FHDHANRS CO4), a large prospective hospital cohort, we studied the incidence of HL in 1992-2007 according to the duration of cART exposure: no cART and year $<1996$, no cART and year $\geq 1996,[0 ; 1],[1 ; 2],[2 ; 3],[3 ; 6]$ and $\geq 6$ months. Relative rates (RR) of HL were estimated using Poisson regression models for the duration of cART exposure, adjusted for age, period of followup, sex and exposure group, migration from sub-Saharan Africa, AIDS stage, and CD4 cell count.

\section{Results}

Our study included 286,806 person-years (PY) of followup and $187 \mathrm{HL}$ cases. The incidence of HL was not associated with the period: 0.79, 0.60, and 0.64 per 1000 PY before 1996, in 1996-1999, and since 2000, respectively $(\mathrm{p}=0.55)$. Risk of HL was significantly related to cART $(\mathrm{p}=0.008)$, being especially high during the first 3 months of use (Table 1). The association remained after adjustment for age, sex and exposure group, migration, and AIDS stage ( $\mathrm{p}=0.006)$, but not in the model

Table 1

\begin{tabular}{llllll}
\hline & No of diagnoses & $\begin{array}{l}\text { Incidence per } \\
\mathbf{1 0 0 0} \mathbf{P Y}\end{array}$ & $\begin{array}{l}\text { Crude RR } \\
\mathbf{9 5 \% C l}\end{array}$ & $\begin{array}{l}\text { Adjusted RR Model 1* } \\
\mathbf{9 5 \% C l}\end{array}$ & $\begin{array}{l}\text { Adjusted Model 2** } \\
\mathbf{9 5 \% C l}\end{array}$ \\
\hline no CART and year<1996 & 43 & 0.58 & $1.35[0.84 ; 2.18]$ & $1.14[0.7 ; 1.85]$ & $0.68[0.4 ; 1.17]$ \\
no CART and year $>=1996$ & 28 & 0.79 & 1 & 1 & 1 \\
{$[0 ; 1]$} & 6 & 2.01 & $3.48[1.48 ; 8.17]$ & $3.09[1.31 ; 7.28]$ & $1.75[0.73 ; 4.19]$ \\
{$[1 ; 2]$} & 2 & 0.68 & $1.19[0.29 ; 4.89]$ & $1.05[0.25 ; 4.33]$ & $0.30[0.04 ; 2.23]$ \\
{$[2 ; 3]$} & 7 & 2.35 & $4.11[1.85 ; 9.13]$ & $3.62[1.62 ; 8.08]$ & $2.17[0.96 ; 4.92]$ \\
{$[3 ; 6]$} & 8 & 0.94 & $1.63[0.76 ; 3.46]$ & $1.43[0.67 ; 3.05]$ & $0.90[0.41 ; 1.94]$ \\
$\geq 6$ & 93 & 0.58 & $1.00[0.69 ; 1.43]$ & $0.83[0.57 ; 1.2]$ & $0.75[0.51 ; 1.10]$ \\
\hline
\end{tabular}

*adjusted for age, sex and exposure group, migration for sub-Saharan Africa, AIDS stage. **adjusted for variables in model 1 and CD4 cell count.

*Correspondence: elanoy@ccde.chups.jussieu.fr

'INSERM, U943, Paris, France; UPMC Univ Paris 06, UMR S943, Paris, France

Full list of author information is available at the end of the article 


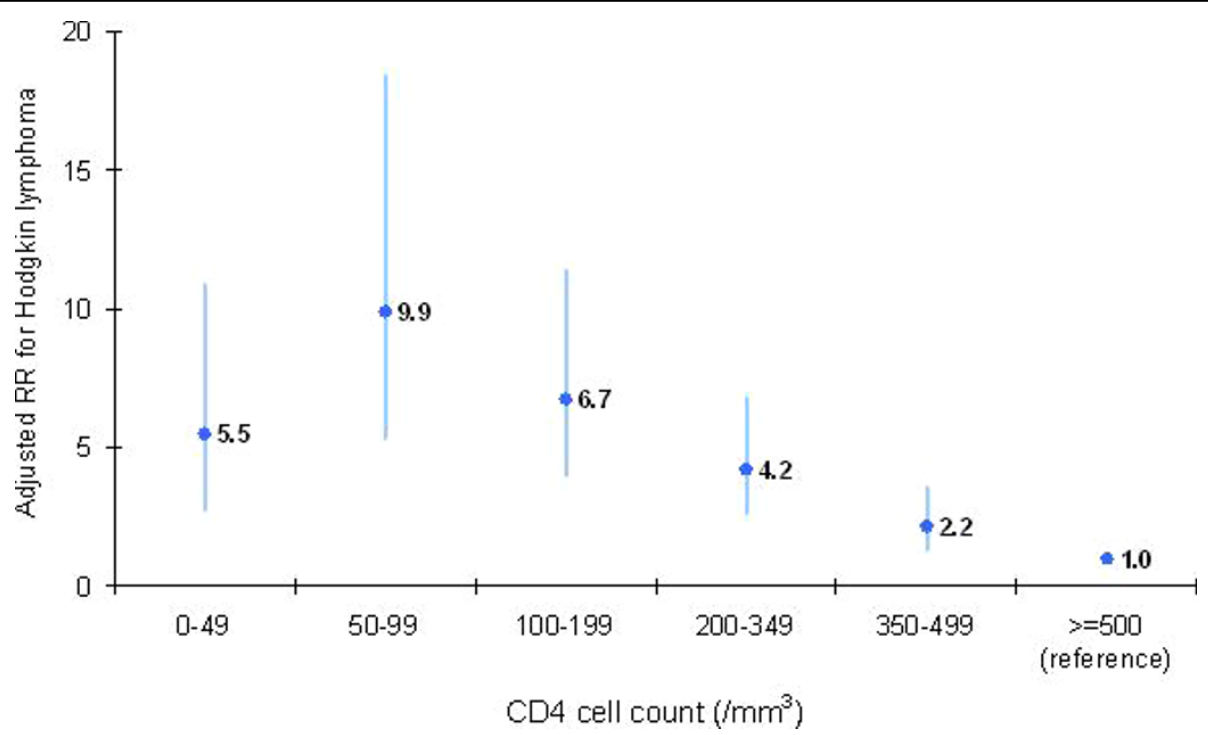

Figure 1

accounting for CD4 cell count $(\mathrm{p}=0.058)$. A peak of $\mathrm{HL}$ incidence was observed for 50-99 CD4 cell count and the association between risk of HL and CD4 cell count remained significant in the multivariate model (Figure 1, $\left.\mathrm{p}<10^{-6}\right)$.

\section{Conclusion}

Our results support that the early cART effect on the risk of HL is largely explained by CD4 count.

\section{Acknowledgements}

This abstract is presented on behalf of the FHDH-ANRS CO4.

This article has been published as part of Infectious Agents and Cancer Volume 5 Supplement 1, 2010: Proceedings of the $12^{\text {th }}$ International Conference on Malignancies in AIDS and Other Acquired Immunodeficiencies (ICMAOI). The full contents of the supplement are available online at http://www.biomedcentral.com/1750-9378/5?issue=S1.

\section{Author details}

'INSERM, U943, Paris, France; UPMC Univ Paris 06, UMR S943, Paris, France. ${ }^{2}$ Division of Cancer Epidemiology and Genetics, National Cancer Institute, Rockville, MD, USA. ${ }^{3}$ Service des Maladies Infectieuses et de Réanimation Médicale, CHU Pontchaillou, Rennes, France. ${ }^{4}$ Département d'immunologie clinique, Hôpital Henri-Mondor, Créteil, France. ${ }^{5}$ Service de Médecine Interne, AP-HP, Hôpital Antoine Béclère, Clamart, France. ${ }^{6}$ Centre de soins de l'infection à VIH, Hôpitaux Universitaires, Strasbourg, France. ${ }^{7}$ Unité CISIH Sud Hématologie VIH, Hôpital Sainte-Marguerite, Marseille, France. ${ }^{8}$ Service de Médecine 5, Hôpital Ambroise-Paré, Boulogne, France. ${ }^{9}$ Service de Maladies Infectieuses et Tropicales, AP-HP, Groupe hospitalier Pitié-Salpêtrière, Paris, France.

Published: 11 October 2010

doi:10.1186/1750-9378-5-S1-A71

Cite this article as: Lanoy et al:: Risk of HIV-associated Hodgkin lymphoma during the first months after initiation of combination antiretroviral therapy. Infectious Agents and Cancer 2010 5(Suppl 1):A71.

\section{Submit your next manuscript to BioMed Central} and take full advantage of:

- Convenient online submission

- Thorough peer review

- No space constraints or color figure charges

- Immediate publication on acceptance

- Inclusion in PubMed, CAS, Scopus and Google Scholar

- Research which is freely available for redistribution 